\title{
Marker-based selection for the ym4 BaMMV-resistance gene in barley using RAPDs
}

\author{
F Ordon ${ }^{1 *}$, E Bauer ${ }^{2}$, W Friedt ${ }^{1}$, A Graner 2 \\ 1 Institute of Crop Science and Plant Breeding, Justus-Liebig-University, Ludwigstr 23, D-35390 Giessen; \\ 2 Institute of Resistance Genetics, Federal Centre for Breeding Research, Graf-Seinsheim-Str 23, D-85461 Grünbach, Germany
}

(Received 17 May 1995; accepted 4 July 1995)

\begin{abstract}
Summary - Studies to identify an RAPD marker linked to the BaMMV/BaYMV resistance gene $y m 4$ were carried out on $F_{1}$ anther derived doubled haploid (DH) barley lines from a cross between the BaMMV/BaYMV susceptible cultivar 'Igri' and the resistant cultivar 'Franka' (ym4). For initial primer screening, bulked segregant analysis was used. Out of 148 decamer primers screened, only primer OP-Z04 revealed polymorphism resulting in an additional 660 bp band in the susceptible bulk. Linkage analysis carried out on $287 \mathrm{DH}$ lines revealed that $\mathrm{OP}-\mathrm{Z} 04 \mathrm{H} 660$ is very closely linked to ym4 facilitating efficient marker-based selection for BaMMV/BaYMV resistance encoded by this gene. Additional studies showed that OP-Z04H660 can discriminate perfectly between resistant (ym4) and susceptible commercial barley cultivars.
\end{abstract}

\section{Hordeum vulgare $=$ barley $/$ barley mild mosaic virus $($ BaMMV $) /$ resistance $/$ RAPD $/$ linkage}

Résumé - Sélection assistée par marqueurs RAPD chez l'orge pour le gène de résistance ym4 au virus de la mosaïque modérée de l'orge. Une étude a été conduite afin d'identifier un marqueur RAPD associé au gène ym4 conférant une résistance contre le BaMMV et le BaYMV. Des lignées haploïdes doublées (HD) d'orge obtenues par androgenèse à partir de la $F 1$ du croisement entre la variété sensible lgri et la variété résistante Franka (ym4) ont été utilisées. La technique d'analyse de mélange en ségrégation a été appliquée par le criblage initial des amorces. Parmi 148 amorces décamériques, seule l'amorce OP-Z04 a révélé un polymorphisme se traduisant par la présence d'une bande additionnelle de $660 \mathrm{pb}$ dans le mélange sensible. Une analyse menée sur 287 lignes HD a montré qu'OPZ04H660 est très étroitement lié à ym4, ce qui rend possible une sélection assistée par marqueur efficace pour la résistance contre le BaMMV et le BaYMV. Une étude complémentaire a mis en évidence qu'OP-Z04H660 permet une discrimination parfaite entre les variétés commerciales résistantes (ym4) et sensibles.

Hordeum vulgare = orge / virus de la mosaïque modérée de l'orge (BaMMV) / résistance / RAPD / linkage

* Correspondence and reprints 


\section{INTRODUCTION}

In Western Europe barley yellow mosaic disease is one of the most important diseases of winter barley today due to a constant spread and high yield losses frequently observed in susceptible winter barley crop. In Germany the disease is caused by a complex of at least 3 viruses or virus strains, ie barley yellow mosaic virus (BaYMV), barley mild mosaic virus (BaMMV) and BaYMV-2 (Huth, 1990; Huth and Adams, 1990). Due to transmission by the soil-borne fungus Polymyxa graminis (Toyama and Kusaba, 1970), chemical measures against the disease are neither efficient nor acceptable for ecological and economical reasons. Therefore, growing resistant cultivars is the only way to avoid high yield losses. Resistance of all present commercial barley cultivars in Germany is presumed to be due to a single recessive gene (ym4), which probably is derived from the Dalmatian landrace 'Ragusa' (Huth, 1985). This gene confers resistance to both BaMMV and BaYMV but is not effective against BaYMV-2. The ym 4 locus is quite well characterized today because it could be located on the long arm of chromosome 3 by means of trisomic and telotrisomic analysis (Kaiser and Friedt, 1989, 1992), and integrated in the RFLP map of barley (Graner and Bauer, 1993). Furthermore, it was shown that $y m 4$ is linked to the esterase isozyme cluster Est1-Est2-Est4 (Le Gouis et al, 1995).

In order to select for resistance in early generations, plants have to be mechanically inoculated with BaMMV in the greenhouse (Friedt, 1983) or have to be tested in infested fields. Both procedures are time consuming and it has to be taken into account that plants showing negative ELISAresults may have escaped infection. Therefore, RAPD (random amplified polymorphic DNA) analysis was carried out in order to identify a marker closely linked to $y m 4$. In comparison to RFLPs, genetic analyses with RAPDs require only minimal amounts of DNA, which can already be extracted in the 2-leaf stage, facilitating a very early selection for resistance. Besides this, RAPD analysis is fast and does not involve the use of radioactivity. For these reasons, RAPDs are better suited to fit the high throughput requirements needed for efficient marker-based selection in practical breeding programmes.

\section{MATERIALS AND METHODS}

Studies were carried out on $287 \mathrm{~F}_{1}$ anther derived doubled haploid (DH) barley lines out of a cross between the BaMMV/BaYMV resistant cultivar 'Franka' (ym4) and the susceptible cultivar 'Igri'. Resistance to BaMMV was tested by mechanically inoculating (Friedt, 1983) 5 plants of each $\mathrm{DH}$ line in 2 replications followed by DAS-ELISA using antiserum kindly provided by Dr W Huth, Federal Biological Research Center, Braunschweig, Germany. DNA of each DH-line was extracted according to Graner et al (1991) and initial primer screening was carried out using bulked segregant analysis (Michelmore et al, 1991) with bulks containing DNA of $15 \mathrm{DH}$ lines each. PCR reaction mixtures $(25 \mu \mathrm{l})$ consisted of $25 \mathrm{ng}$ genomic DNA, $0.4 \mathrm{mM}$ dNTPs, $6 \mathrm{mM} \mathrm{MgCl}, 0.3 \mu \mathrm{M}$ of a random decamer primer (Operon Technologies Inc) and $1.5 \mathrm{U}$ AmpliTaq DNA-polymerase Stoffel-fragment (Perkin Elmer) and its corresponding reaction buffer (Perkin Elmer). The mixture was overlaid with mineral oil and the amplification process was carried out in a Perkin Elmer 480 DNA thermocycler. The temperature profile was as follows: an initial denaturation step $\left(94^{\circ} \mathrm{C} / 4 \mathrm{~min}\right)$ was followed by 45 cycles of $94^{\circ} \mathrm{C} / 1 \mathrm{~min}$, $36^{\circ} \mathrm{C} / 1 \mathrm{~min}$, and $72^{\circ} \mathrm{C} / 2 \mathrm{~min}$. The heating rate from $36^{\circ} \mathrm{C}$ to $72^{\circ} \mathrm{C}$ was restricted to $5^{\circ} \mathrm{C} / \mathrm{min}$ (modified according to Sobral and Honeycutt, 1993) and the polymerization time was extended for 4 s/cycle at $72{ }^{\circ} \mathrm{C}$. Fragments were separated on a $2 \%$ agarose gel (sea plaque agarose (FMC): standard agarose $(F M C)=1: 1$ ) with $3 \mathrm{~V} / \mathrm{cm}$ and visualized on a UV screen $(286 \mathrm{~nm})$. Linkage analysis was carried out using Mapmaker computer software (Lander et al, 1987). Crossover units were converted to map distances (centiMorgans, cM) by applying the Kosambi function (Kosambi, 1944).

\section{RESULTS}

Out of 148 decamer primers screened to identify polymorphisms between the resistant and susceptible bulk, only primer OP-Z04 (5'-AGGCTGTGCT-3') revealed polymorphism resulting in an additional $660 \mathrm{bp}$ band in the susceptible bulk. Other bands generated by this primer were identical (fig 1). In order to investigate whether this polymorphism is linked to the $y m 4$ resistance gene, $\mathrm{DH}$ lines and their parents (cvs 'Franka' and 'Igri') were analysed. As shown in figure 1, the $660 \mathrm{bp}$ band is present in the susceptible $\mathrm{cv}$ 'Igri' but missing in the resistant cv 'Franka'. The same was true for resistant and susceptible $\mathrm{DH}$ lines derived from the cross between these cultivars. By testing $287 \mathrm{DH}$ lines it turned out that OP-Z04H660 cosegregates with the RFLP marker MWG010, which is very closely linked to $y m 4$ (fig 2). In fact, no recombination between MWG010 and OP-Z04H660 was observed up to now, although the distance between these markers was calculated to be $0.7 \mathrm{cM}$ by Mapmaker. This may be due to the fact that not all $\mathrm{DH}$ lines 


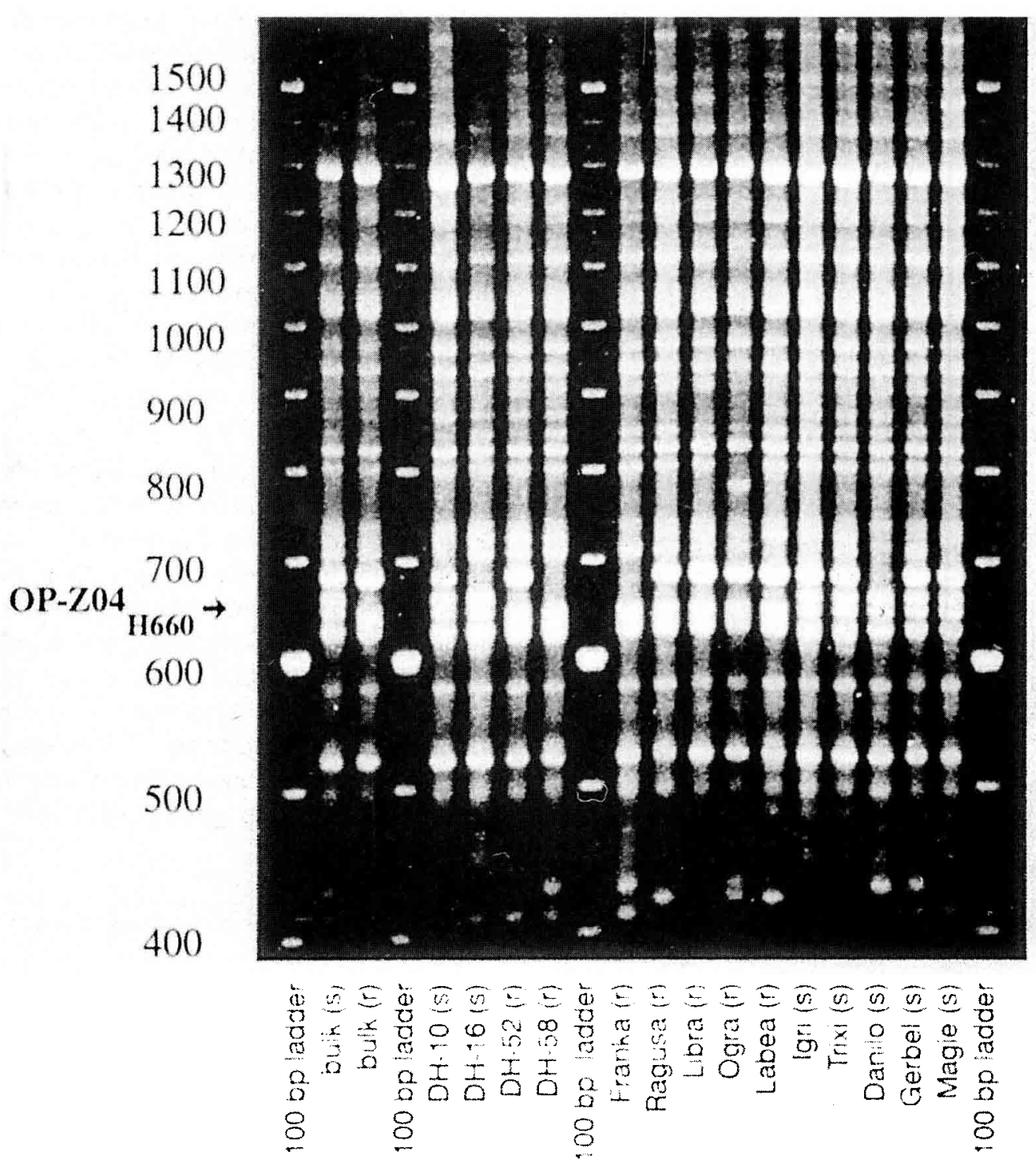

Fig 1. OP-Z04 RAPD pattern of bulks, DH lines and cultivars susceptible (s) and resistant ( $r, y m 4)$ to BaMMV.

included in RFLP mapping have been tested in RAPD-analysis. Further experiments were undertaken in order to test whether OP. Z04H660 is specific for the cross 'Igri' $x$ 'Franka' or working in different genetic backgrounds. For this reason German susceptible and resistant commercial barley cultivars as well as the possible donor of $y m 4$, ie the variety 'Ragusa', were analysed for the presence or absence of OPZ04H660, respectively. In each case OPZ04H660 could discriminate perfectly between resistant and susceptible cultivars, as the additional 660 bp band was present in all susceptible but missing in all resistant varieties (table I). Furthermore, it turned out that exotic varieties carrying BaMMV-resistance genes different from ym4 (Götz and Friedt, 1993), eg, 'Bulgarian 347', 'Turkey 235' and 'Russia 57', exhibit the addi- tional 660 bp band in the same way as susceptible German cultivars.

\section{DISCUSSION}

The results show that the RAPD marker OP. $\mathrm{Z} 04 \mathrm{H} 660$ is closely linked to $y m 4$ in the same way as the RFLP marker MWG010 (Graner and Bauer, 1993) and, therefore, is well suited to facilitate marker-assisted selection for BaMMVresistance encoded by this gene. The use of OPZ04 enables barley breeders to select efficiently for the presence of ym4 without mechanical inoculation or time-consuming field tests. In comparison to the RFLP marker MWG010 the RAPD marker OP-Z04H660 is better suited for use in practical breeding programmes, because RAPD 


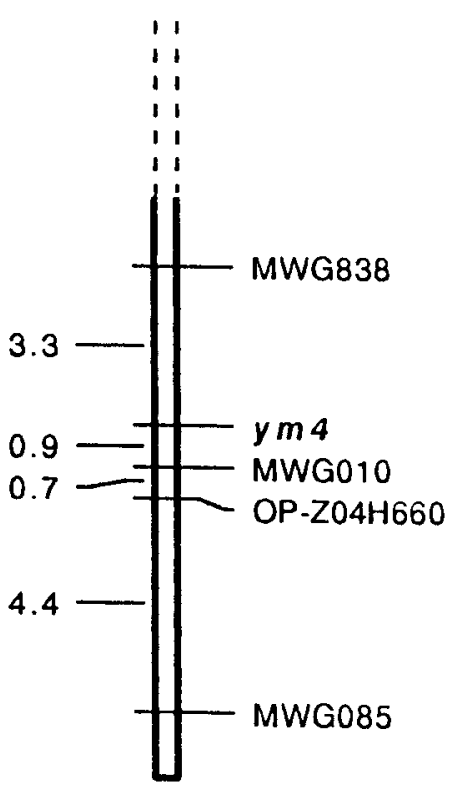

\section{chromosome 3HL}

Fig 2. Distal portion of the map of chromosome $3 \mathrm{HL}$ based on the analysis of $287 \mathrm{DH}$ lines. analysis is faster and does not involve the use of radioactivity. However, as RAPD markers are inherited in a dominant-recessive manner, they do not discriminate between heterozygous and homozygous susceptible plants, $e g$, in $F_{2}$. This may be a problem in selecting for BaMMV-resistance, because it was shown by segregation analyses that the BaMMV-resistance of all barley cultivars tested up to now is inherited entirely recessively (Ordon and Friedt, 1993). However, this disadvantage of RAPDs in comparison to RFLPs is only true for using segregating $F_{2}$-populations instead fo $\mathrm{DH}$ lines.

Besides Ym4 different recessive genes conferring resistance at least to BaMMV were identified (Götz and Friedt, 1993). Future work will concentrate on defining RAPD markers for these resistance genes. The identification of RAPD markers for different resistance genes, which may even act in a specific way to the different viruses of the barley yellow mosaic virus complex (Ordon et al, 1992), offers the opportunity to combine different resistance genes in one variety efficiently (pyramiding of resistance genes). Efficient RAPD-

Table I. Usefulness of OP-Z04H660 in different genetic backgrounds to detect the presence or absence of $y m 4$.

Resistant cv

$O P-Z 04 H 660$

Ragusa

Franka

Brunhild

Jana

Sonate

Romanze

Express

Labea

Columbo

Venus

Asorbia

Gauloise

Libra

Noveta

Nixe

Blanca

Babylone

Viresa

Epic

Sympax

Krimhild

Target
Susceptible cv

OP-Z04H660

Igri

Magie

Alraune

Gerbel

Corona

Baretta

Catinka

Danilo

Hanna

Grete

Copia

Traxo

Catania

Tapir

Cita

Nebelia
$+$

$+$

-: absence of OP-Z04H660 linked to resistance $(y m 4) ;+$ : presence of OP-Z04H660 linked to susceptibility. 
assisted introgression of new resistance genes as well as combining different resistance genes, may avoid the further selection of novel strains of BaYMV and BaMMV as already reported from Japan (Kashiwazaki et al, 1990).

\section{REFERENCES}

Friedt W (1983) Mechanical transmission of soil-borne barley yellow mosaic virus. Phytopath $Z 106,16-22$

Götz R, Friedt W (1993) Resistance to the barley yellow mosaic virus complex. Differential genotypic reactions and genetics of BaMMV-resistance in barley (Hordeum vulgare L). Plant Breed 111, 125131

Graner A, Bauer E (1993) RFLP mapping of the $y m 4$ virus resistance gene in barley. Theor Appl Genet 86, 689-693

Graner A, Jahoor A, Schondelmaier J et al (1991) Construction of an RFLP map in barley. Theor App/ Genet 83, 250-256

Huth W (1985) Versuche zur Virusdiagnose und Resistenzträgerherstellung in Gerste gegen Barley Yellow Mosaic Virus. Vortr Pflanzenzüchtg 9, 107 120

Huth W (1990) The yellow mosaic inducing viruses of barley in Germany. Proc 1st Symp Intern Working Group Plant Viruses with Fungal Vectors, Braunschweig, Germany, August 21-24, 113-115

Huth W, Adams MJ (1990) Barley yellow mosaic virus (BaYMV) and BaYMV-M: 2 different viruses. Intervirology 31, 38-42

Kaiser R, Friedt W (1989) Chromosomal location of resistance to barley yellow mosaic virus in German winter-barley identified by trisomic analysis. Theor App/ Genet 77, 241-245

Kaiser R, Friedt W (1992) Gene for resistance to barley mild mosaic virus in German winter-barley located on chromosome 3L. Plant Breed 108, 169172

Kashiwazaki S, Nomura K, Watanebe K et al (1990) Barley yellow mosaic virus and barley mild mosaic virus: strains and host resistance. Proc 1st Symp Intern Working Group Plant Viruses with Fungal Vectors, Braunschweig, Germany, August 21-24, 105-108

Kosambi DD (1944) The estimation of map distances from recombination values. Ann Eugen 12, 172-175

Lander ES, Green P, Abrahamson J et al (1987) MAPMAKER: an interactive computer package for constructing primary genetic linkage maps of experimental and natural populations. Genomics 1, 174181

Le Gouis J, Erdogan M, Friedt W, Ordon F (1995) Potential and limitations of isozymes for chromosomal localization of resistance genes against barley mild mosaic virus (BaMMV). Euphytica 82, 25-30

Michelmore RW, Paran I, Kesseli RV (1991) Identification of markers linked to disease-resistance by bulked segregant analysis: a rapid method to detect markers in specific genomic regions by using segregating populations. Proc Natl Acad $\mathrm{Scl}$ USA 88, 9828-9832

Ordon F, Friedt W (1993) Mode of inheritance and genetic diversity of BaMMV resistance of exotic barley germplasms carrying genes different from ym4. Theor Appl Genet 86, 229-233

Ordon F, Erdogan M, Friedt W (1992) Genetics of resistance of barley to soil-borne mosaic viruses. Reproductive Biology and Plant Breeding, Book of Poster Abstracts, XIIIth EUCARPIA Congress, July 6-11, Angers, France, 707-708

Sobral BWS, Honeycutt RJ (1993) High output genetic mapping of polyploids using PCR-generated markers. Theor App/ Genet 86, 105-112

Toyama A, Kusaba T (1970) Transmission of soilborne barley yellow mosaic virus. 2. Polymyxa graminis Led as vector. Ann Phytopathol Soc Jpn $36,223-229$ 